\title{
ESL Teachers' Perceptions toward the Practices and Prospects of Autonomous Language Learning
}

\author{
Melor Md Yunus ${ }^{1} \&$ Nur Dalila Mohd Arshad ${ }^{1}$ \\ ${ }^{1}$ Faculty of Education, Universiti Kebangsaan Malaysia, Malaysia \\ Correspondence: Nur Dalila Mohd Arshad, Faculty of Education, Universiti Kebangsaan Malaysia, 43600 Bangi, \\ Selangor Darul Ehsan, Malaysia. Tel: 60-16-220-7104. E-mail: ma.nurdalila@gmail.com
}

Received: June 11, 2014 Accepted: September 30, 2014 Online Published: December 20, 2014

doi:10.5539/ass.v11n2p41 URL: http://dx.doi.org/10.5539/ass.v11n2p41

\begin{abstract}
The latest shift in Malaysia Education Blueprint (MEB 2013-2025) has emphasized on the usage of Autonomous Language Learning (ALL) as a teaching and learning approach. In reality, most of the Autonomous Learning traits seem to be missing in the traditional learning process due to the exam-oriented education system that has been applied in Malaysia since the past decades. The objective of this study is to explore the teachers' perceptions towards ALL practices and prospects knowing that their roles are very crucial in developing Autonomous Learner. A survey was conducted among 35 in service English teachers teaching in Malaysia public secondary schools to explore their insights and views regarding their perceptions, practices and prospects of learner autonomy in their classrooms. The findings revealed that the teachers are very positive towards the implementation despite the discouraging situation of ALL among students.
\end{abstract}

Keywords: autonomous language learning, ESL, teachers, perceptions

\section{Introduction}

The world today is in need of human capital that is more competitive. A competitive individual is known to be innovative, creative, proactive, motivated, highly skilled, flexible, available, and most important to have complex and critical thinking (Rivas, 2013). It is said that these traits of human capital can be shaped by the practice of learner autonomy (Bullock, 2011; Camilleri, 1999; Yoshiyuki, 2011). However, fostering learner autonomy requires appropriate cooperation between teachers and learners. In the process of language learning, active learners reflect on how they learn and analyse their learning methods. Learners should decide and reflect themselves whether they need improvements or not to remain stagnant. In many cases, students are not expected to reflect upon, analyse and evaluate their learning process in the current situation of language learning.

Autonomous learners are those who positively accept responsibility for their own learning (Holec, 1981; Little, 1991). Learners will be motivated when they realize that they hold the responsibility for their language learning development (Al Asmari, 2013; Jiao, 2005; Little, 2007 Borg \& Al-Busaidi, 2012). Motivation should enhance the sense of responsibility among the learners in conducting their language learning process. The autonomous learner should understand learning objectives and goals before making initiative to strive towards their own learning, without ignoring to share insights during monitoring progress and evaluating their learning process. Teacher should guide their students to achieve realistic and measurable goals in formal education context-being reflective and possessing self-awareness will lead to better learning (Pintrich, 2000; Schunk, 2005; Borg \& Al-Busaidi, 2012).

According to Al Asmari (2013), language learning process works through learners' own reflection on how they learn and it makes learners active in the sense that they learn to analyse their learning strategies. It has to be admitted that this trait is missing in traditional language teaching process and students are not expected to reflect upon their own learning. Malaysia Education system is still practicing traditional classroom system where teachers act as the authority that provides learners with knowledge which has resulted to the hindrance of ALL. Teacher is the person in charge in determining what and how to learn. This way of teaching will create passive learners. Passive learners only absorb the information provided to them by their teacher without any reflections, analysis, and evaluation of the information. Learner autonomy and teacher autonomy are interrelated as they need each other to work out as the teaching and learning process happens. Autonomous teachers should be able to guide their student to take responsibility with proper guidance and know when and how to guide. Teachers and 
learners' roles should be identified and introduced. Autonomous teachers should supply their students with appropriate tools and offer them fair opportunities to practice in the language classroom. A teacher needs to observe the change assuming that he or she are willing to become more autonomous by shifting from teaching knowledge-based to supervising students learning-based. Teachers role is a very crucial element towards developing ALL as chance to practice LA depends on teacher ability to create a culture that welcomes LA. It is vital to understand teachers' views about ALL which is mirrored through their practices and strategies in promoting learner autonomy in their classrooms.

MEB 2013-2025 has emphasized on the notion of autonomous teaching and learning and one would like to explore the notion of teacher autonomy in Malaysian context to shed some light focusing on the teachers' perspectives toward the implementation that will change the role of teachers in term of pedagogical aspect. According to Borg and Al-Busaidi (2012), various studies regarding autonomous learning have been conducted since the past 30 years. However, the researches are very limited toward its relationship with teachers only. The lack of understanding of how teachers interpret learner autonomy somehow hinders the possibilities of ALL's practice. The aims of this paper are to explore the perceptions of teachers regarding the current situation of ALL's practices among students and the current practices that the teachers employ in creating autonomous language learning environment. The practices of strategies that the teachers think might work on the development of ALL has also being explored and at the same time the challenges that they faced in developing ALL are taken into account. The prospect of ALL in secondary school has also been investigated towards the development of ALL.

\section{Literature Review}

One of the teachers' roles is to create a supportive autonomous learning environment in the classroom and many advocates agreed that that the role of a teacher has become the core in developing learner autonomy (Hurd, Beaven, \& Ortega, 2001; Benson, 2009; Asmari, 2013). Supportive learning environment could stimulate learners' awareness towards independent learning such as addressing learners' past learning experience and performing specific induction session that will help learners to understand the lesson that will be taught that day. However, teachers' perception and practicality towards the concept of learner autonomy may vary according to cultural settings and unsurprisingly the differences affect the methods to promote learner autonomy to language learners as the level of readiness for learner autonomy differs across cultures and educational background (Yıldırım, 2008 \& 2012). Therefore, in order to build a design or adapting activities in promoting autonomous learning, it is vital to understand teachers' perceptions, practices and beliefs toward the notion of learner autonomy.

The notion of learner autonomy has diverted the roles of learners and teachers inside the classroom where learners are required to be more responsible towards their own learning with the role of teachers being kept up. In developing learner autonomy, teachers should provide necessary assistance to help learners to be more independent inside and outside of the classroom. Teachers and peers presence is very essential where Communicative Language Teaching (CLT) can be exercised to aid in developing learner autonomy through group work that will assist in achieving learners shared goals and gradually build the sense of interdependence among them (Little, 1991; Littlewood, 1999; Benson, 2001, Y1ldırım, 2008). Considering the importance of learners' autonomy, teachers are encouraged to foster learner autonomy as soon as possible in the classroom setting. Theoretically, everything seems simple but in reality the application and implications might change according to the current setting. An understanding towards the teachers' perceptions and beliefs of learner autonomy could provide guidance for curriculum development, revision materials, classroom practice and teacher training (Little, 1995; Ho \& Crookall, 1995; Scharle \& Szabo, 2000; Chan, 2003). Due to the perception and realization differences, it is crucial to study the autonomy-related perspectives from various teachers and learners from all over the world and this study is an attempt to that direction.

\subsection{Teachers' Perceptions of Autonomous Language Learning}

Even Learner Autonomy is widely explored in various cultures in terms of definition, characteristics as well as justification, teachers' perceptions toward understanding learner autonomy seem to be neglected. One might said that further research on teachers perspectives and beliefs regarding learner autonomy is very essential as teachers are the individuals who directly deal with the learners. The teachers are one of the important elements in realizing learner autonomy; therefore, their perspectives and ideas are always valid to be taken into account. Al Asmari (2013) agreed that revealing teachers' beliefs in LA is an important gap to fill as teachers play a central role in developing LA. However, very limited researches have been carried out in exploring teachers' perspectives and how ESL teachers define learner autonomy in various contexts and educational settings 
worldwide (Borg, 2010).

In Oman, LA has become a goal as represented in the new Basic Education Curriculum (Al-Shaqsi, 2009). The teachers in Oman define LA as an independent learning, self-evaluation, taking responsibility, and cooperating. Teachers also believe that their students have the capacity of exercising LA. However, the findings have been questioned by Barillaro (2013) who stated that the 'surprisingly high' positive results might be influenced by the current educational policy in Oman where the teachers may have responded accordingly with regards to the policy. Camilleri (1997) is one of the pioneer advocates who has explored the teachers' views of autonomous learning. His works involved teachers' background of various European Countries. He found out that teachers always have willingness to change and develop their teaching practice. He also proved that autonomous learning can be incorporated in various areas of teaching such as selection of material, classroom management, learning strategies, and also learning styles. He also indicated that the reluctance of teachers to implicate learners in aims and methodological decision. The constraints from higher authorities also made it hard toward promoting learner autonomy.

Some teachers might want to involve their learners into the teaching and learning processes by letting them to set some objectives, choose some materials, or evaluate the course. However, some learners may not be coming to class and be ready to take such kind of responsibility and they should not always be interpreted as lack of interest to the class as they might still be under the influence of their previous learning habits. It is important for these teachers to understand that the idealistic of learner's autonomy are deeply influenced by Western values. Creating students' independence might not always work in the same way all over the world as students came from different cultures (Kubota, 2002) and it is proven that LA varies across culture construct (Schmenk, 2005; Adamson, 2004; Lacey, 2007; Asmari, 2013). A study from Adamson (2004) reported that the idea to create independent, reflective learners in tertiary settings encounter problems with some Asian learners who may find it hard to renounce their old strategies. Asmari (2013) in his study in Saudi Arabia, has discovered that some teachers are reluctant in bringing more learner autonomy into their classroom assuming that the students came from cultures that highly depending on the teachers and institution authorities.

\subsection{Autonomous Learning in Malaysian Context}

Autonomous Learning was first recognized in 1990 when 'Self Access Learning' was introduced in Malaysia since 1990 in primary school and 1995 in secondary school in English subject. However, the implementation is never encouraging since Malaysia Education system has been exercising 'the spoon feeding' system; passing down knowledge to their learners without expectation of getting the students to involve. In Malaysian context, Thang \& Azarina (2007) found out that a majority of UKM, UPM and OUM learners are very teacher-centred. However, they do possess autonomous learning characteristics such as awareness of the importance of reading widely and acquiring appropriate learning strategies. Seng (2003) discovered that despite of the fact that the positive effects of autonomous learning activities, there is little indication that such approach is widely practised in Malaysian schools. There is a general presumption that a student-centred pedagogy is inferior to a teacher-centred pedagogy in increasing students' cognitive performance.

Knowing this issue, Malaysia's Ministry of Education has stressed out on a student-centred learning approach in MEB 2013-2025. This curriculum approach will try to embed a balanced set of knowledge and skills such as creative and critical thinking, problem-solving, and leadership. The Ministry believed that in creating a highly competitive human capital, Autonomous Learning should be mastered by the young generation as well as in creating lifelong learners who are equipped with high order thinking skills. It would be great if this neglected learning approach can be exercised as early as possible to equip the learners with the characteristic of autonomous learner by the time they enrol in the tertiary level of education. Teachers role is very important in realizing autonomous learning as Little (n. d.) suggested, teachers roles and responsibilities in realizing this aspiration consist of using the target language as the medium of communication and instruction, involving learners in good learning activities that require them to discuss, analyse, and evaluate in target language, assist learners in setting their learning goal, choosing their activities, and reflect on their work (in target language). According to Little, teachers should ask their learners to identify individual learning goals but they need to achieve them through collaborative works and every learning plans and project should be recorded and written for future reflections.

\section{Methodology}

The study employed a survey-based data collection on secondary school teachers' current practices and prospects of learner autonomy. In this study, a number of 150 online questionnaires were distributed to a group of secondary school ESL teachers. However, only 35 teachers responded after two gentle reminders. The data 
were derived out of the 35 teachers' responses. The questionnaire were adapted from Al Asmari (2013) consist of 30 items on a five-point scale of agreement that are separated in three sections: the current situation, the practices and the prospects of learner autonomy. The survey items aim to explore their ideas as to how far students should be involved in decision-making processes regarding common aspects of their own learning. The first section of the questionnaire explored the present situation of learner autonomy activities and students' involvement in the process of decision making, while the second section concentrated on teaching practices through which teachers want to teach learner autonomy and problems they encountered, and the third section are meant to explore the teachers' prospects of promoting learner autonomy. A statistical analysis was derived from the online statistical calculation done by Google Form Apps. The analysis was followed by the discussion and suggestion for developing learner autonomy at secondary school level especially for ESL learners.

\section{Findings and Discussions}

The data should describe and provide some information regarding the current practice of ALL activities among secondary school students including the teacher's effort in developing ALL skill among their learners and their views regarding the notion of ALL. The data supplied by the teachers based on the questionnaire were tabulated and analysed through mean. The questionnaire served as the survey tool to investigate the present situation of learner autonomy activities in ESL classrooms from the teachers' perspective and its future and prospects. It also revealed current teaching practices among ESL teachers and strategies for developing learner autonomy in ELT. The questionnaire were divided into three sections:1) The current practice of ALL; 2) Developing Autonomous Language Learning Practices; and 3) Autonomous Language Learning-Teachers' suggestions.

\subsection{The Current Practice of ALL}

The data from the first section of the questionnaire reported a discouraging state of ALL activities among secondary school students according to the teachers' perspectives. The situation was determined from the mean score from the basis of the higher the mean (maximum is 5), the more encouraging the current situation of ALL activities occurred. From the study, most of the statements scored below 4 which portrayed a very discouraging situation of current ALL activities in secondary schools level. The only statement that scored high is the first statement 'Students compare their result with the results of other students' with mean score 4.49. Teachers noticed that their students evaluate their performance in tests and exam and compare it with their friends. This statement showed that they do possess the urge to compete in their learning achievement and they do evaluate themselves based on their results. The second statement 'Students are keen to perform excellent in the classroom' has supported the first statement with mean score 3.86. The result showed that the students do want to perform in their classroom and to compare their results with their friends. The following 3 statements were also quite favour by the teacher: 'Students try to create a link with the learned concepts when they study a new grammar rule' with mean score 3.14, 'Students motivate themselves in learning English' with mean score 3.11, and 'Students share their learning goals with the teachers' with mean score 3.00. In the other hand the least favourite statements are 'Students can comment on selection of the study material' with mean score 2.77 , 'In the beginning of the academic session, students identify their own strengths and weaknesses' with mean score 2.77 and 'Students discover language concepts on their own rather than waiting for the teacher' 2.14 . The scores are shown below.

Table 1. The current practice of ALL

\begin{tabular}{lc}
\hline Items & Mean score \\
\hline Students compare their result with the results of other students. & 4.49 \\
Students are keen to perform excellent in the classroom. & 3.86 \\
Students try to create a link with the learned concepts when they study a new grammar rule. & 3.14 \\
Students motivate themselves in learning English. & 3.11 \\
Students can comment on selection of the study material. & 2.77 \\
In the beginning of the academic session, students identify their own strengths and & 2.77 \\
weaknesses & 2.86 \\
Students evaluate their progress in learning English during the session & 3.00 \\
Students share their learning goals with the teachers. & 2.83 \\
Students set up their own learning goals. & 2.14 \\
\hline Students discover language concepts on their own rather than waiting for the teacher \\
\hline
\end{tabular}


From the findings, one might say that the current situation of ALL from the teachers perspectives was not promising and the fact that the first and second statement indicated that the students shows the characteristic of autonomous learning such compare their result with their friends and worried about their performance might be because of the of Malaysian education system exercises the exam oriented assessment. The findings might describe that students nowadays learn just for the sake of getting good grades without understanding their learning purposes and goals. If this is true, everything will be wasted and at the end of the day they actually learned nothing. This kind of education system hinders the true purpose of gaining knowledge by overemphasizing on student scores as the benchmark of successful student and student abilities (NST, 2012). From the table, we can see the gap between low scores statements and the two highest score statements. The gap somehow showed that the low mean scores revealed very discouraging autonomous learning situations. One might said that our learner traits are very much influenced by the previous education system. As from teachers perspectives, learner motivation to learn English is not very encouraging and might be influenced by how teachers interprets and expect from their learners to be autonomous due to the notion of autonomous is very hard to defined as the definition are subjective and varied (Benson, 2006). Motivation plays a unique and critical role in shaping autonomous language learners and it is the key to successful language learning (Dornyei, 1994, 2006). However, in Malaysia, due to exam oriented basis, learners motivation and learning objectives are not parallel, and bounded to the faith in authorities of teachers and textbooks that hinders students intrinsic motivation due to extrinsic goals such as grades and task completion (Borg \& Al-Busaidi, 2012; NST, 2012).The main idea of ALL is to emphasize the role of learners rather than teachers by focusing on the process rather than the outcomes. Teachers should start to acknowledge the fact that working together with students in the idea of learner-centered tasks does not mean losing their authority in the classroom. ALL should be viewed as the collaborative effort that will empower student oriented teaching (Brown, 1994) and the importance of teachers roles should never been neglected or hindered since the responsibilities of learning should be shared equally between teachers and learners. ALL should be able to encourage learners in identifying and developing their learning objective and introduced them with the notion and practices of lifelong learning (Jacobs \& Farrell, 2001; Camilleri, 1999; Little, 1991; Dam, 1995; Nunan, 1997; Benson, 2001). From the findings, teachers indicated that most of the learners do not have the ability to identify language concepts on their own that they rather wait for their teachers to inform them or to teach them the concepts. However, sharing goal setting and decision making will actually encourage learners in taking responsibilities or taking charge on their own learning and but the teachers possess lack of awareness in regard to the importance of these two activities during learning session. The teachers need to realize that some students might not be learning anything unless they has a clue on what they are trying to achieve (Cotterall, 2000). At the end of the day, the students might feel lost and they will neglect self-evaluation process during ELT session resulting them to be unaware of their strength and weaknesses toward their learning. This condition demonstrates a very teacher-centred practice in the current situation of ESL classroom (Reinders \& Lazaro, 2011; Al Asmari, 2013). Our 'spoon feeding' system has left negative effects upon our learners' learning style and preferences which result to the lack of self-confidence among students since their knowledge are solely based on theories that they cannot applied them in their daily lives. As they cling on their teachers, they limit their ability to think independently and critically resulting in poor creativity skills, hinder their true potential and confidence. Borg \& Al-Busaidi (2012) supported that confident language learners are more autonomous compared to less confident language learners.

\subsection{Developing Autonomous Language Learning Practices}

The second section explored the teaching strategies that train ALL in secondary school Level. For autonomous pedagogy, teacher should be able to play their roles as facilitator, counsellor and resource. This three roles have been identified by Voller (1997) toward the development of ALL. The data reveals the teaching strategies that have been practiced by the teacher that embark on the practice of ALL. The most favoured statements were 'Communicative skills are taught from the very beginning' (4.11), 'Group discussion creates interest in English language learners' (4.06), and 'I prefer learner-centred plus teacher's facilitation pattern in my teaching' (4.26). Meanwhile the least favoured statements were 'Poor teaching facilities are the main problem in English teaching' (3.31), 'English study skills mainly focus on the communication skills' (3.20), 'Decisions are made on the basis of teacher learner agreement and negotiations' (3.34), and 'Poor learner's quality is the main problem in English teaching' (3.34). The detailed results are shown in Table 2.

From the findings, the teachers are very positive in developing ALL in terms of developing learners' communication skills and practicing and exercising ALL activities such as sharing learning objectives, giving responsibilities, making decision of what and how they want to learn. Teachers will practice to be more like facilitators and classroom managers as well as encouraging learners to engage with outside of classroom learning 
and involving them in various group discussion as they encourage learners to learn English (Camilleri, 1997; Asmari, 2013). Not every teacher has confidence in their learners to perform classroom activities. It might be due to the fear of giving responsibilities that actually will hinder the practice of ALL. Nowadays with the existence of ICT, students can surprisingly be creative if they are given a certain amount of time and the freedom of how they want to learn and when they want to learn as they became more motivated and responsible (Yunus, Salehi, \& Chenzi, 2012; Borg \& Al-Busaidi, 2012). In addition, ICT also has the capability in assisting and stimulating students to be more creative and help to develop ALL as well as improving teaching and learning quality (Yunus \& Suliman, 2014).

Table 2. Teaching strategies

\begin{tabular}{ll}
\hline Items & $\begin{array}{l}\text { Mean } \\
\text { score }\end{array}$ \\
\hline $\begin{array}{l}\text { Communicative skills are taught from the very beginning. } \\
\text { Group discussion creates interest in English language learners }\end{array}$ & 4.11 \\
$\begin{array}{l}\text { I prefer learner-cantered plus teacher's facilitation pattern in my teaching } \\
\text { The best strategy to encourage creativity among students in language use is to assign } \\
\text { home-based language tasks and projects to the students }\end{array}$ & 4.06 \\
$\begin{array}{l}\text { English study skills mainly focus on the communication skills } \\
\text { Only partial learners' autonomy is possible and the teacher should decide what the learners do } \\
\text { independently }\end{array}$ & 3.26 \\
$\begin{array}{l}\text { All decisions are made on the basis of teacher learner agreement and negotiations. } \\
\text { Students' poor responsibility is the main problem in English teaching. }\end{array}$ & 3.20 \\
Poor learner's quality is the main problem in English teaching. & 3.34 \\
Poor teaching facilities are the main problem in English teaching. & 3.63 \\
\hline
\end{tabular}

Some of the teachers believed that learner autonomy is impossible to be achieved and only partial learner autonomy activities are possible to be exercised. This might due to the fact that teachers have to follow a strict curriculum plans and to chase and finish the syllabus given by the ministry. This situation jeopardizes the overall ALL practice as it hinders and affects the ALL execution (Smith \& Palfreyman, 2003). Students' poor sense of responsibility somehow turns out to be the main problem in English teaching. Teachers felt that learners did not take the responsibilities in their learning. One might say that the ability to take responsibility is to be earned and not to be given. Teachers should know how to train their students toward becoming autonomous language learner and in times, autonomy should be given gradually so students will have the time to absorb and manage the burden and can learn to not only to take responsibility but to sustain the role of autonomous language learners. If the responsibility is blindly given to the students without any briefing (sharing learning objectives, methods and preferences), there is the chance for responsibility negligence because they did not understand and feel the importance of the specific tasks and the purpose of the lesson, as suggested by previous advocates that teachers and learners should work together as a community and communicate using the target language to shape the collaborative process (Little, Dam, \& Timmer, 1998; Al Asmari, 2013; Borg \& Al-Busaidi, 2012). According to the teachers, poor learners' quality contributed as the main issue in ELT. Student at some point did not possess a good learner quality. Learners' quality includes the ability to think critically and to learn, the ability to communicate, the ability to identify learning objectives, futures and social responsibility (Camilleri, 2007; Cotterall, 1995; Smith \& Palfreyman, 2003). Learners somehow just wanted to finish their school without knowing and understanding the purpose of learning and how to make use of their knowledge (Smith et al., 2011). As the 21 st century learners, they should be able to develop clear understanding of how to learn best and how to gain knowledge in the future. In addition, poor teaching facilities are also one of the issues in ELT. Supportive environments are of the most crucial elements towards the development of ALL. A good teaching and learning facility should embark students engagement that identified as one component necessary for successful learning, together supported with standards, teachers, and system that can positively impact educational results (Moore, 2008; Roberts, Edgerton, \& Peter, 2008; Buckley, Schneider, \& Shang, 2005). This means that a good facility will assist in the effectiveness of ELT. The supportive physical environment will establish a positive learning process. The integration of ICT and positive classroom environment will create more inviting learning environment (Groundwater-Smith et al., 2011; Yunus, Salehi, \& Chenzi, 2012). 


\subsection{Autonomous Language Learning-teachers' Suggestions}

ALL requires the shift of teacher's role towards the development of learner autonomy. Appropriate classroom environment is very essential to support teacher-student interaction in order to create various learning opportunities. The survey results exposed teachers' futuristic approach toward developing ALL in their classroom. Overall data in this section showed that the teachers are quite positive to integrate learner autonomy in their teaching. The favoured statements include 'Reflecting with the students on the teaching/learning process helps me identify some of their problems and find ways of solving them' (4.34), 'I think continuous professional development is important to improve teaching learning process' (4.29), 'Focusing on learner training makes it possible for me to observe improvement in the students' attitudes and communicative competence' (4.20), 'To be able to implement a learner-centred pedagogy and develop my students' learning competencies, I need to improve my theoretical knowledge in this field' (4.20), 'Providing learner training contributes to the development of autonomy as a teacher' (4.14), 'Providing learner training strategies prepares the teachers to implement future action research projects' (4.00). While the least favoured statements were 'Learner training component is included in the teacher development programs' (3.63) and 'I receive all necessary theoretical support from the university' (3.51). Below are the detailed mean score of the analysis data.

Table 3. Autonomous language learning-teachers' suggestions

\begin{tabular}{|c|c|}
\hline Items & $\begin{array}{l}\text { Mean } \\
\text { score }\end{array}$ \\
\hline I think continuous professional development is important to improve teaching learning process & 4.29 \\
\hline $\begin{array}{l}\text { Reflecting with the students on the teaching/learning process helps me identify some of their } \\
\text { problems and find ways of solving them }\end{array}$ & 4.34 \\
\hline $\begin{array}{l}\text { Focusing on learner training makes it possible for me to observe improvement in the students' } \\
\text { attitudes and communicative competence. }\end{array}$ & 4.20 \\
\hline $\begin{array}{l}\text { Providing learner training strategies prepares the teachers to implement future action } \\
\text { research projects. }\end{array}$ & 4.00 \\
\hline Providing learner training contributes to the development of autonomy as a teacher. & 4.14 \\
\hline $\begin{array}{l}\text { To be able to implement a learner-cantered pedagogy and develop my students' learning } \\
\text { competencies, I need to improve my theoretical knowledge in this field. }\end{array}$ & 4.20 \\
\hline Learner training component is included in the teacher development programs. & 3.63 \\
\hline Learner training component fosters reflective attitude towards my practice. & 3.89 \\
\hline Learners should be as autonomous as possible, and teachers should ensure this autonomy. & 3.94 \\
\hline I receive all necessary theoretical support from the university. & 3.51 \\
\hline
\end{tabular}

The overall data from the last section show a very encouraging and positive response from teachers towards the exercising of ALL. The idea of teachers as learners is very essential since they will get engaged in career- long profesional learning, Attending related lectures, workshops, and seminars will provide teachers with the latest research findings and they will be able to cope with the need of this industrial age requirements. After all, every hard work that the teachers contribute are for the sake of learners development so they will be able to contribute to their country.at the same time, teachers professional development are very essential so they can play their role actively in school as well as in the learning communities (Groundwater-Smith, 2011). Reflections, discussions, and students' feedbacks on teaching and learning process will assist and improve in their further ELT process (Peters, 2010). Teachers will make adjustment accordingly in future classes so that they can convey their knowledge more effectively and maximize the process of knowledge transfer. Moreover, learner training also contributes in shaping autonomous language learners as they practiced strategic learning strategies (Benson \& Voller, 1987; O’Malley \& Chamot, 1990) and teachers find it easier to observe their attitudes and communicative competence. Towards fostering learner autonomy, teachers must first understand and explore the essence of ALL practice so that they can maximize the benefit of ALL. While employing ALL, teacher and learners must together being autonomous (Al Asmari, 2013; Borg \& Busaidi, 2012; Little, n. d.; Neupane, 2010). As supported from the finding, teachers agree that learner training will contribute in the development of learner autonomy. Successful language learners that employ specific language learning techniques can help them to take more responsibilities and become ALL, but these techniques are not autonomous in isolation as they need other elements toward the development of autonomous learning (de León, 2010; Al Asmari, 2013) 
In this study, teachers have also admitted that they possess limited understanding towards ALL and upon the implementation of ALL they need to understand the notion of learner autonomy and learner training. It is crucial for teachers to understand three facts regarding autonomous learning as proposed by Little (1999). He indicated that the three facts are: 1 . Autonomous learning varies according to learner metacognitive abilities, 2 . The differences of autonomous learning abilities influenced by learners genetics form and it differs among individuals and it changes and bend across cultures, and also 3 . The fact that the capacity of autonomous learning is develop by practice require it to be nurtured and maintained. In the meantime, some teachers indicated that learner training component is not included in their teacher development program. It might due to the fact that they did not understand the true notion of learner training and autonomous learning (Borg \& Busaidi, 2012; de León, 2010; Al Asmari, 2013) or the fact that they are truly not exposed to the learner training component in their university years. Learner training is one area of methodology that encouraged students to focus on their learning (Benson, 1995) and according to him; learner training has 6 major forms. These forms are:

1) Direct advice on how to learn languages independently.

2) Methods and materials based on 'good language learner' research.

3) Using open-ended methods and materials.

4) 'Synthetic' approaches drawing on a wide range of sources.

5) 'Integrated' approaches that treat learner training as a part of general language learning.

\section{6) 'Self-directed' approaches}

Most of the teachers understand that they play a major role in ensuring the successful practice of ALL. They realized that the fact that student being autonomous, teacher roles may never be hindered and it only shift from being a teacher as a sole source of knowledge to being the facilitator, the mentor, and the guidance to keep learning progress in tracks and to reflect upon their decision and their student decision (Al Asmari, 2013). Their role is very important and crucial toward the development of learner autonomy by providing motivation and encouragement for learner to take responsibility, to develop positive learning habits, to be more independent in learning, to take charge in practicing language skills and communicate inside and outside of classrooms (Thanasoulas, 2000). However some of the teachers stated that they did not receive necessary theoretical support from the university regarding learner autonomy. They wish that they should be exposed to learner autonomy in terms of theoretical support during their degree years and some of them might never came across to the notion of learner autonomy during their in service teaching program. It is suggested that all universities should exposed their teacher learners towards the notion of learner autonomy in term of theories and practices so they can exercise it in during their service in schools.

\section{Conclusion}

This present study revealed that the teachers are willing to practice ALL in their classrooms by sharing the authority in their ELT with their learners. However, from the teachers' perspectives, students in multi-cultural classrooms may not all be equally ready for ALL especially in terms of taking responsibility. Therefore, towards developing ALL, teachers should be aware of their students' educational backgrounds and perceptions that relate to learner autonomy. It does not seem possible to talk about completely non-autonomous or completely autonomous students. Learners must first learn to take responsibility of themselves first and then take responsibility of being autonomous learners and it is important for language teachers to be able to determine where and when to start practicing ALL as students from different backgrounds carry different perceptions of responsibility and some of those perceptions might not fit into 'ideal' type of autonomous learner. Further understanding and exposure of ALL is very essential to educate or to train the teachers towards the development of ALL in their classrooms. Educational Training Department should come out with courses and workshops that can train the teachers for better practices of ALL to make sure positive and successful implementation.

In addition, Learners training is one of the crucial elements toward the successful practice of ALL. Learners should be able to identify and employ the suitable strategies with their learning styles and preferences since learner training has the capability in fostering and developing learner autonomy. Teachers should exposed their learners with various learning strategies so they can identify and exercise the specific strategies that suit them best to improve their English learning and skills. ALL will not only benefit them in language and communication skills but as well as to train them to be autonomous in all subject $\mathrm{s}$ and fields and to practice the lifelong learning to become more creative and innovative learners and human capital in this challenging industrial age. Therefore teachers should realize that they are no longer sole educational resource of their learners but they are also the manager, facilitator, mentors and counsellors. They should start giving their learners some basic or small 
autonomy of their learning process and encourage them to reflect upon their learning outcomes. Despite one of the objectives of curriculum is to train independent learners that can manage their own learning, their independency is not encouraging. We have to accept that teachers and the curriculum are the main aspects in developing ALL.

From this study, to sum up, it is suggested that teachers should start practicing teacher and learner autonomy and they should realize that they play a critical role in developing ALL among their students. They should be able to evaluate their students' needs and identify their students learning preferences independently as all students possessed different learning styles. Teachers should identify and prepare variety learning resources that can cater variety students learning styles and able to assess their students' performance fairly. Special programs and courses related to ALL should be given to teachers from time to time to keep them up to date in order to practice and to improve autonomous teaching and learning.

\section{References}

Adamson, J. (2004). Investigating college student attitudes towards learning English and their learning strategies: Insights from interviews in Thailand. The Journal of Asia TEFL, 1, 47-70.

Al-Asmari, A. R. (2013). Practices and Prospects of Learner Autonomy: Teachers' Perceptions. English Language Teaching Journal. http://dx.doi.org/10.5539/elt.v6n3p1

Al-Shaqsi, T. S. (2009). Teachers' beliefs about learner autonomy. In S. Borg (Ed.), Researching English language teaching and teacher development in Oman (pp. 157-165). Muscat: Ministry of Education, Oman.

Barillaro, F. (2011). Teacher perspectives of learner autonomy in language learning MA dissertation. TESOL Centre. Sheffield Hallam University.

Benson, P. (2001). Teaching and researching autonomy in language learning. English Language Teaching, 6(3). Harlow: Longman. Retrieved from http://www.ccsenet.org/elt

Benson, P. (2006). Autonomy in language teaching and learning. Language Teaching.

Benson, P. (2009). Making sense of autonomy in language learning. In R. Pemberton, S. Toogood, \& A. Barfield (Eds.), Maintaining control: Autonomy and language learning (pp. 13-26). Hong Kong: Hong Kong University Press. http://dx.doi.org/10.5790/hongkong/9789622099234.003.0002

Benson, P., \& Voller, P. (1997). Autonomy and Independence in Language Learning. London: Longman.

Borg, S., \& Al-Busaidi, S. (2012). Learner Autonomy: English Language Teachers' Beliefs and Practices. London: British Council.

Brown, D. H. (1994). Teaching by Principles: An Interactive Approach to Language Pedagogy. Englewood Cliffs: Paramount.

Bullock, D. (2011). Learner self-assessment: An investigation into teachers' beliefs. ELT Journal, 62(2), 114-125. http://dx.doi.org/10.1093/elt/ccq041

Camilleri, G. (1997). Learner autonomy: The teachers'views. Retrieved November 24, 2012, from http://www.ecml.at/documents/pubCamilleriG_E.pdf

Camilleri, G. (Ed.). (1999). Learner Autonomy-The Teachers' Views. Strassbourg: Council of Europe Publishing.

Camilleri, G. A. (2007). Pedagogy for autonomy, teachers' attitudes and institutional change: A case study. In M. J. Raya, \& L. Sercu (Eds.), Challenges in teacher development: Learner autonomy and intercultural competence (pp. 81-102). Frankurt: Peter Lang.

Chan, V. (2003). Autonomous Language Learning: The teachers' perspectives. Teaching in Higher Education, 8(1), 33-54. http://dx.doi.org/10.1080/1356251032000052311

Cotterall, S. (1995). Readiness for autonomy: Investigating learner beliefs. System, 23, 195-206. http://dx.doi.org /10.1016/0346-251X(95)00008-8

Cotterall, S. (1999). Key variables in language learning: What do learners believe about them? System, 27, 493-513. http://dx.doi.org/10.1016/S0346-251X(99)00047-0

Cotterall, S. (2000). Promoting learner autonomy through the curriculum: Principles for designing language courses. ELT Journal, 54(2), 109-117. http://dx.doi.org/10.1093/elt/54.2.109

Dam, L. (1995). From theory to classroom practice. Dublin: Authentik.

de León, G. L. D. G. (2010). Learner autonomy in language learning? Is that possible?

Dickinson, L. (1993). Talking shop: Aspects of autonomous learning, An interview with Leslie Dickinson. ELT Journal, 47(1), 330-341. 
Dornyei, Z. (1994). Motivation and Motivating in the Foreign Language Classroom. The Modern Language Journal, 78, 273-284. http://dx.doi.org/10.1111/j.1540-4781.1994.tb02042.x

Dornyei, Z. (2006). Motivation, Language Attitudes and Globalization. Clevedon: Multilingual Matters Ltd.

Esch, E. (1996). Self-access and the adult language learner. London: CILT.

Groundwater-Smith, S. (2011). Teaching challenges and dilemmas (4th ed.). Susan Groundwater-Smith Robyn Ewing Rosie Le Cornu.

Ho, J., \& Crookall, D. (1995). Breaking with Chinese cultural traditions: Learner autonomy in English language teaching. System, 23(2), 235-243. http://dx.doi.org/10.1016/0346-251X(95)00011-8

Holec, H. (1981). Autonomy and Foreign Language Learning. London: Pergamon Press.

Holliday, A. (2003). Social autonomy: Addressing the dangers of culturism in TESOL. In D. Palfreyman, \& R. C. Smith (Eds.), Learner Autonomy across Cultures: Language Education Perspectives (pp. 110-126). London: Palgrave Macmillan.

Hurd, S., Beaven, T., \& Ortega, A. (2001). Developing autonomy in a distance language learning context: Issues and dilemmas for course writers. System, 29(3), 341-355.

Jack, B., Mark, S., \& Yi, S. (2005). LAUSD school facilities and academic performance. Building Educational Success Together Initiative, 1-12. Retrieved from http://www.21csf.org/csf-home

Jacobs, G. M., \& Farrell, T. S. (2001). Paradigm Shift: Understanding and Implementing Change in Second Language Education. Teaching English as a second or foreign language. Retrieved September 9, 2012, from http://teslej.org/ej17/a1.html

Jiao, L. (2005). Promoting EFL learner autonomy. Sino-US English Teaching, 17, 27-30.

Joshi, K. R. (2011). Learner Perceptions and Teacher Beliefs about Learner Autonomy in Language Learning. Nepal English Language Teachers'Association.

Kenny, B. (1993). For More Autonomy. System, 21(4), 431-442. http://dx.doi.org/10.1016/0346-251X(93) 90055-L

Kubota, R. (2002). The author responds: (Un)ravelling racism in a nice field like TESOL. TESOL Quarterly, 36, 84-92. http://dx.doi.org/10.2307/3588363

Lacey, F. (2007). Autonomy, never, never, never! Independence, 42, 4-8.

Lamb, T. E., \& Reinders, H. (Eds.). (2008). Learner and teacher autonomy: Concepts, realities, and responses. Amsterdam: John Benjamins. http://dx.doi.org/10.1075/aals.1

Little, D. (1991). Learner autonomy: Definitions, issues and problems. Dublin: Authentik.

Little, D. (1995). Learning as dialogue: The dependence of learner autonomy on teacher autonomy. System, 23(2), 175-182. http://dx.doi.org/10.1016/0346-251X(95)00006-6

Little, D. (n. d.). Learner autonomy: Drawing together the threads of self-assessment, goal-setting and reflection. Retrieved from http://www.archive.ecml.at/mtp2/Elp_tt/.../06\%20Supplementary\%20text.pdf

Little, D., Dam, L., \& Timmer, J. (Eds.). (1998). Focus on Learning Rather than Teaching: Why and How? Papers from the International Association of Teachers of English as a Foreign Language (IATEFL) Conference (Krakow, Poland, May 14-16, 1998) (pp. 38-56). Dublin: Centre for Language and Communication Studies.

Littlewood, W. (1999). Defining and developing autonomy in East Asian contexts. Applied Linguistics, 20(1), 71-94. http://dx.doi.org/10.1093/applin/20.1.71

Ministry of Education Malaysia. (2012). Malaysia Education Blueprint 2013-2025.

Moore, K. J. (2008, February 13). Modern public facilities: Investing in the future. Testimony of Kathleen J. Moore before Committee on Education and Labor United States House of Representatives (pp. 1-12). Washington, DC: United States House of Representatives.

Neupane, M. (2010). Learner Autonomy: Concept and Considerations. Journal of NELTA, 15(1-2).

New Straits Times. (2012, March 11). Exam-oriented system: Evaluate students on all their abilities. Retrieved from http://www.nst.com.my/opinion/letters-to-the-editor/exam-oriented-system-evaluate-students-on-alltheir-abilities-1.58757

Nunan, D. (1997). Designing and adapting materials to encourage learner autonomy. In P. Benson, \& P. Voller (Eds.), Autonomy and independence in language learning (pp. 192-203). London: Longman.

O'malley, J. M., \& Chamot, A. U. (1990). Learning strategies in second language acquisition. Cambridge 
University Press. http://dx.doi.org/10.1017/CBO9781139524490

Palfreyman, D. (Eds.). (2003). Learner autonomy across cultures: Language education perspectives. Basingstoke: Palgrave Macmillan. http://dx.doi.org/10.1057/9780230504684

Peters, E. E. (2010). Shifting to a student-centered science classroom: An exploration of teacher and student changes in perceptions and practices. Journal of Science Teacher Education, 21(3), 329-349.

Pintrich, P. R. (2000). An Achievement Goal Theory Perspective on Issues in Motivation Terminology, Theory, and Research. Contemporary Educational Psychology, 25, 92-104.

Reinders, H., \& Lazaro, N. (2011). Beliefs, identity and motivation in implementing autonomy: The teachers' perspective. In G. Murray, X. Gao, \& T. Lamb (Eds.), Identity, motivation, and autonomy in language learning (pp. 125-142). Bristol: Multilingual Matters.

Rivas, L. (2013). Need for Developing Human Capital Management. Retrieved from http://eujournal.org/index.php/esj/article/viewFile/1249/1258

Roberts, Edgerton, \& Peter. (2008). Facility Conditions and Learning Outcomes. Retrieved from http://www.cea-ace.ca/sites/default/files/EdCan-2008-v48-n3-Roberts.pdf

Scharle, A., \& Szabo, A. (2000). Learner Autonomy: A Guide to Developing Learner Responsibility. Cambridge: Cambridge University Press.

Schmenk, B. (2005). Globalizing learner autonomy. Tesol Quarterly, 39(1), 107-118. http://dx.doi.org/10.2307/ 3588454

Schunk, D. H. (2005). Self-regulated learning: The educational legacy of Paul R. Pintrich. Educational Psychologist, 40(2), 85-94. http://dx.doi.org/10.1207/s15326985ep4002_3

Seng, T. W. (2003). Student-centred pedagogy: Lest we forget.

Smith, R. C. (2000). Starting with ourselves: Teacher-learner autonomy in language learning. In B. Sinclair et al. (Eds.), Learner autonomy, teacher autonomy: Future directions (pp. 89-99). London: Longman.

Smith, R. C. (2001). Teacher education for teacher-learner autonomy. Language in language teacher education.

Smith, R. C., \& Yıldırım, O. (2008). Turkish EFL learners' readiness for learner autonomy. Journal of Language and Linguistic Studies, 4(1), 65-80.

Smith, R. C., \&Palfreyman, D. (Eds.). (2003). Learner autonomy across cultures: Language education perspectives. Basingstoke: Palgrave Macmillan.

Thanasoulas, D. (2000). What is learner autonomy and how can it be fostered? Internet TESL Journal, 6, 1-11.

Thang, S. M., \& Alias, A. (2007). Investigating readiness for autonomy: A comparison of Malaysian ESL undergraduates of three public universities.

Voller, P. (1997). Does the teacher have a role in autonomous learning? In P. Benson, \& P. Voller (Eds.), Autonomy and Independence in Language Learning (pp. 98-113). London: Longman.

Yıldırım, O. (2012). A Study on a Group of Indian English as a Second Language Learners' Perceptions of Autonomous Learning. Turkish Online Journal of Qualitative Inquiry. Retrieved from http://www.tojqi.net/articles/TOJQI_3_2/TOJQI_3_2_Article_2.pdf

Yoshiyuki, N. (2011). Teachers' readiness for promoting learner autonomy: A study of Japanese EFL high school teachers. Teaching and Teachers Education, 275(5), 900-910.

Yunus, M. M., \& Suliman, A. (2014). Information \& Communication Technology (ICT) Tools in Teaching and Learning Literature Component in Malaysian Secondary Schools. Asian Social Science, 10(7). http://dx.doi.org/10.5539/ass.v10n7p136

Yunus, M. M., Salehi, H., \& Chenzi, C. (2012). Integrating Social Networking Tools into ESL Writing Classroom: Strengths and Weaknesses. English Language Teaching, 5(8).

\section{Copyrights}

Copyright for this article is retained by the author(s), with first publication rights granted to the journal.

This is an open-access article distributed under the terms and conditions of the Creative Commons Attribution license (http://creativecommons.org/licenses/by/3.0/). 